\title{
Regeneration or Degeneration? An Untold Story of Urban Change in Turkish Metropolitan Cities
}

\author{
By Tolga Levent*
}

In the year 1999, a high-intensity earthquake hit Turkey and caused massive damage and destruction. After this earthquake, the stakeholders of urban development realized the fact that the possibilities for such losses in Turkish cities are relatively high due to the low physical qualities of building stock. Depending on a broad consensus, urban regeneration appeared as the strongest option by replacing unqualified buildings with the qualified ones, which increased the numbers of both theoretical studies focusing on urban regeneration and urban regeneration projects. The dominance of urban regeneration on urban planning, however, does not mean that they are problem-free in Turkish case. There is a theoretical ambiguity about the definition, input-output, and processes of urban regeneration which causes certain problems related to the economic and social dimensions of cities. With reference to many cases, it can be easily said that the costs of these problems are more than the benefits of urban regeneration projects. In this respect, this study aims to concentrate on the problems of urban regeneration practices to understand whether urban regeneration projects create a kind of urban degeneration. In the first part, there are basic theoretical discussions about urban regeneration. The second part is about a historical description of urban regeneration in the Turkish context by focusing especially on the methods and priorities in different periods since they are important by understanding the ongoing processes of urban regeneration. The third part concentrates on the problems of urban regeneration with reference to its underestimated economic and social dimensions. The conclusion of the study aims to discuss the potential qualities of urban regeneration in Turkish context and to determine possible modifications in the processes, priorities, and principles of existing urban regeneration practices so that the possibility of urban degeneration could decrease.

Keywords: Degeneration, Regeneration, Turkey, Urban Development.

\section{Introduction}

In the year 1999, Turkey had experienced a high-intensity earthquake in Kocaeli province. This earthquake, known as the 1999 Marmara Earthquake, caused massive damage and destruction in the surrounding cities such as İstanbul, İzmit, and Sakarya ${ }^{1}$. According to the official records of the year 2002, 17.480 people died, 43.953 people were injured, and 505 people became permanently disabled with this earthquake (Herdem 2011:193).

Most of these losses directly resulted from the damages in buildings. There were 213.843 residential units and 30.540 workplaces, having different levels of

\footnotetext{
*Assistant Professor, Mersin University, Ciftlikkoy Yerleskesi, Turkey.

${ }^{1}$ The cost of this earthquake is seriously high. According to different public institutions and nongovernmental organizations (NGO), it was estimated between \$12-19 billion, which was nearly 6$10 \%$ of gross domestic product (GDP) of Turkey at those days (Herdem, 2011:193).
} 
damages, although they were in the relatively developed part of Turkey (Herdem 2011:193). Just after the societal shock of these large-scale losses, all the stakeholders of urban development realized the facts that the possibility of such kinds of damage and destruction is relatively high due to the low physical qualities of building stock in Turkey and that these unqualified buildings should be renewed as fast as possible (Levent 2015a).

In a very short period of time, urban regeneration appeared as the main strategy, or the strongest option, by replacing unqualified buildings with the qualified ones. The method of approaching the urban regeneration was quite interesting in those days. It was considered a magical tool for urban development, or a kind of panacea for all kinds of urban problems (Levent 2015a). Such a consideration had increased the popularity of the concept, both in theoretical and practical domains. In the theoretical domains, it became one of the widespread concepts, resulting to the accreditation of more graduate studies on different aspects of urban regeneration ${ }^{2}$. In the practical domain, the number of urban regeneration projects has increased radically as if they are the only legal interventions in the urban space ${ }^{3}$. All these changes have turned the last two decades into a new period within the history of urban development in Turkey, in which, urban regeneration has dominated almost everything in the cities.

The apparent dominance of urban regeneration on the urban planning agenda does not imply that urban regeneration projects are problem-free in Turkey. Most of the problems have emerged due to the control of urban regeneration processes by certain stakeholders such as subcontractors and land developers. They have had concrete expectations like more floor area and more monetary profit within the urban regeneration process. Because of the theoretical ambiguities and the lack of consensus about the definition, input-output, and processes of urban regeneration, they could manage to fulfill these expectations with the help of their clientelistic ties. However, such kinds of fulfillment do not create win-win situations for all. Especially, with reference to low-income property owners and tenants, it can be easily said that the costs of urban regeneration projects are more than their benefits and there emerge some problems related to the economic and social dimensions of cities, with which the viability of urban regeneration is called into question (Levent 2015b).

\footnotetext{
${ }^{2}$ The number of graduate studies focusing on different aspects of urban regeneration has increased constantly since the year 1998. In the 1998-2002 period, there were only 3 graduate studies on urban regeneration. Their number increased to 28 in the 2003-2007 period; and to 70 in the 2008-2012 period. In the last period, there were 130 such graduate theses. A similar pattern can be observed with reference to $\mathrm{PhD}$ dissertations. There was only one dissertation on urban regeneration in the 2003-2007 period. The number of such dissertations increased to 16 in the 2008-2012 period; and to 27 in the 2013-2017 period. (These numbers are derived from the website of National Thesis and Dissertation Center of Turkey, https://tez.yok.gov.tr/UlusalTezMerkezi, Last accessed: May 2018)

${ }^{3}$ It is difficult to derive the total numbers of residential units produced by urban regeneration projects. The only reliable data about residential units produced by urban regeneration could be derived from Housing Development Administration of Turkey. According to the records of this administration, in the year 2010, the number of residential units produced by urban regeneration and squatter prevention projects was approximately 51.000 and increased to approximately 143.000 in the year 2018. The increase is approximately $280 \%$ in eight years. (https://www.toki.gov.tr, Last accessed: June 2018)
} 
The aim of this study is to discuss the problems of urban regeneration in order to reply to the question whether urban regeneration projects create a kind of urban degeneration or not, at least, with reference to certain groups. In the first part of the study, there are theoretical discussions about urban regeneration. These discussions not only concentrate on the conditions imposing urban regeneration but also aim to define urban regeneration. In the second part, there is a brief historical description of urban regeneration in the Turkish context. This description focuses mainly on the methods and priorities of urban regeneration, which are important for understanding the positive and negative aspects of ongoing processes of urban regeneration. The third part concentrates on the problems of urban regeneration with reference to the economic and social dimensions of cities, which are generally underestimated within the process. Understanding these problems might help to reply to the question whether the results of certain urban regeneration projects could be defined as urban degeneration or not. The conclusion of the study aims to discuss the potential qualities of urban regeneration in Turkish context and to determine possible modifications in the processes, priorities, and principles of existing urban regeneration practices so that the possibility of urban degeneration could decrease.

\section{Theoretical Discussions of Urban Regeneration}

Cities are in a process of continuous evolution. The trends directing these evolutions are rapid means of transportation development and communication; cities metropolisation as a globalization expression interpreted by cities; increasing individuals autonomy within more socialized and complex systems; and the development of society strongly influenced by the notion of risk which forces new ways of expressing and organizing individual and collective responsibilities (Ascher 2001, cited in Ginot 2010:1).

Although the trends are limited in quantity, they are absolutely rich in quality and result in varying sociospatial repercussions in different cities. Their repercussions embodied through the changes and transformations observed in urban structures and the sociospatial elements of those structures. Understanding and explaining these changes and transformations is not so easy since they relate to economic, social, physical and environmental dimensions of daily lives intertwined together (Roberts 2000, Levent and Sarkaya Levent 2010). Independent from the possibility of achieving comprehensive explanations about these changes and transformations, it can be easily stated that certain cities, or certain parts in cities, might have an adaptative capacity to these changes and transformations. In other words, they are more successful in adapting to those trends, which generally results in economic, social, cultural enhancements in the urban environments and improvements in physical urban space. In the opposite, cases where there are limited adaptation capacities, cities, or certain parts in cities, generally experiencing economic problems such as high unemployment rates; socio-demographical problems relating to loss of a part of the population (Cheshire and Hay 1989:10); or physical problems such as structural and physical 
decay (Lang 2005), urban degradation and deterioration (Levent 2015a) and urban deprivation (Tsenkova 2002:1).

Urban regeneration obviously focuses on these decayed, degraded, deteriorated and deprived urban spaces where different problems are concentrated. According to Roberts $(2000 ; 17)$, urban regeneration is "comprehensive and integrated vision and action which leads to the resolution of urban problems and which seeks to bring about a lasting improvement in the economic, physical, social and environmental condition of an area that has been subject to change". It aims an amalgam of policies, strategies and action plans for comprehensive rehabilitation andlor restructuring of urban space (Akkar 2006:29, Özden 2000:257, Yiğitcanlar 2001:55). It deals with the physical and developmental change of an urban environment with a strategic and long-term purpose (Couch 1990:2, Roberts 2000:18). The basic concerns of urban regeneration are the re-growth of the lost economic activity; restoration of the social function; provision of social inclusion for excluded individuals and groups; and restoration of environmental quality and damaged ecological balance (Couch and Fraser 2003:2). These concerns present the fact that urban regeneration associates different social and economic dimensions of cities with their physical and environmental conditions. It does not isolate the urban problems from the relevant dimensions but considers them concurrently. This means a kind of sociospatial consideration of the urban problems. Moreover, it provides policy alternatives to meet the immediate demands for spatial developments, which is, in general, crucial for a well-functioning planning system (Roberts 2000, Akkar 2006, Uzun 2006).

\section{Historical Description of Urban Regeneration in Turkish Context}

Cities are complex structures, changing and transforming continuously. The changes and transformations are multi-dimensional in essence, which emerge with the interrelations of economic, political, social and cultural dimensions of daily practices (Levent and Sarkaya Levent 2010). This multi-dimensionality complicates the process of achieving a comprehensive explanation about cities.

However, without facing up to this multi-dimensionality, it is possible to claim that these changes and transformations might result in either improvements or degradation/deterioration in urban environments. In other words, they might end up with positive or negative qualities in urban spaces. These degraded and deteriorated urban environments, where negative qualities are highly concentrated, are the main focuses of urban regeneration.

Urban regeneration aims an amalgam of policies, strategies, and action plans for comprehensive rehabilitation and/or restructuring of degraded/deteriorated urban environments (Akkar 2006:29, Özden 2000:257, Yiğitcanlar 2001:55) without excluding economic and social dimensions of them. It provides policy alternatives to meet the immediate demands for spatial developments that are quite crucial for a well-functioning planning system in general (Roberts 2000, Akkar 2006, Uzun 2006). 
In the Turkish urban context, however, urban regeneration is considered in a reductionist manner. Different than the comprehensiveness in theoretical definition, Turkish practices of urban regeneration generally dabble in economic and social dimensions of degradation/deterioration in an urban environment and focus substantially on the physical dimension of the urban environment (Levent 2015a).

Urban regeneration is a relatively new concept in Turkey. Up to the 1980s, there had been a limited number of projects and theoretical studies about urban regeneration. This paucity of projects and studies was quite understandable when they are considered in relation to the priorities of urban planning of those days. Until that period, Turkish urban planners had been quite experienced by developing the cities through spatial enlargement (Levent 2010a). According to them, transforming the agricultural lands into building lots and producing urban patterns in rural-urban fringes were the main tasks of planning endeavors. The basic tool for this transformation and production was local development plans (Levent 2015a). Although hard-to-define the nature of rural-urban fringes (Pryor 1968) made such planning endeavors complicated, this strategy was clearly consistent, since, in that period, metropolitan cities in Turkey were under significant pressures of rural migration (see Table 1), the results of which became an uncontrollable informal residential development in form of squatters, surrounding those metropolitan cities (Sağlam 2006).

Table 1. The Percentage of Squatters and Squatter People in Urban Populations*

\begin{tabular}{|l|c|c|c|}
\hline Years & $\begin{array}{c}\text { Number of } \\
\text { Squatter Units }\end{array}$ & $\begin{array}{c}\text { Number of } \\
\text { Squatter People }\end{array}$ & $\begin{array}{c}\text { The Percentage of Squatter } \\
\text { People in Urban Populations }\end{array}$ \\
\hline $\mathbf{1 9 5 5}$ & 50,000 & 250,000 & 4.7 \\
\hline $\mathbf{1 9 6 0}$ & 240,000 & $1,200,000$ & 16.4 \\
\hline $\mathbf{1 9 6 5}$ & 430,000 & $2,150,000$ & 22.9 \\
\hline $\mathbf{1 9 7 0}$ & 600,000 & $3,000,000$ & 23.6 \\
\hline $\mathbf{1 9 8 0}$ & $1,150,000$ & $5,750,000$ & 26.1 \\
\hline $\mathbf{1 9 9 0}$ & $1,750,000$ & $8,750,000$ & 33.9 \\
\hline $\mathbf{1 9 9 5}$ & $2,000,000$ & $10,000,000$ & $35.0^{* *}$ \\
\hline
\end{tabular}

Source: Keleş R, (1997), Kentleşme Politikası (4. Basım), İmge Kitabevi, Ankara.

*There have been no exact official numbers of squatters in Turkey between the years 1955-1995. The researchers have obtained the numbers about squatters and squatter people from the local authorities.

**Since there was not an official census study in the year 1995, the exact number of urban population was missing for this year. Therefore, the percentage of squatter people in urban populations depends on prediction.

Although these processes had seemed unchangeable for decades, they started to change within the 1990s. Slowdowns in migrations and, thus, decreases in urbanization rates resulted in different patterns of urban redevelopment in and around central areas instead of territorial expansions in the periphery. There emerged redevelopment pressures on certain squatter areas in metropolitan cities, mostly on the ones close to the city centers, since these areas generally offer high monetary profits for land developers. The obvious shift of the interest of urban planning from developing the cities on agricultural lands to redeveloping the cities 
in built environment necessitated a new planning approach having a capacity to define urban problems of the built environment and to solve them. The emergence of the idea of urban regeneration was mainly related to this new planning approach.

At first, squatter areas were conceptualized as the only urban problem in metropolitan cities, forcing urban planners to get focused on them (Türel et al. 2005). For most of them, the solution to this problem was to redevelop and regenerate squatter areas with local rehabilitation plans (Özdemir Sönmez 2006:121, Özdemir et al. 2005), although one of the main functions of these plans was to produce a kind of legitimization of squatters. Redeveloping squatter areas as formal housing areas had lots of similarities with urban regeneration. This is why the implementation with reference to these plans was perceived as urban regeneration in that period. Although long-term rehabilitation of the social and economic conditions of these areas was excluded (Uzun 2006:50), these plans, somehow, manage to redevelop squatter areas. The basic actors of this process were the subcontractors who had limited capital. The paucity of their capital forced them to the plot-by-plot redevelopment of the squatter areas. This is why the overall consideration of squatter areas was left out of the account and why the urban qualities of these areas were relatively low after the redevelopment (Özdemir Sönmez 2006:126).

Since the results of these efforts were not so successful in increasing the urban qualities through the redeveloped squatter areas, there had been searches for new models of urban regenerations in the 1990s. Two famous examples, in the national context, are the Dikmen Valley Urban Regeneration Project and Portakal Çiçeği Valley Urban Regeneration Project in Ankara, the capital city of Turkey. The innovative aspect of the models of these projects was the promotion of publicprivate partnerships for the ease of implementation (Uslu and Yetim 2006) which was not properly experienced before. Another important aspect of these projects, different from the previous examples, was that they were considering regeneration areas in a totality. They not only aimed a high-quality residential area with proper social facilities and technical infrastructure, but also new social, cultural and recreational focal points for the city of Ankara, which meant relatively higher qualities of the urban environment.

These pioneer projects inspired lots of significant urban regeneration projects in different cities. These projects similarly focused on degraded and deteriorated residential areas in transition zones and aimed to produce continuities in urban patterns. Although the general characters of these projects are better than the previous ones, there was still a lack of spatial plans and spatial development programs framing these projects. They were simultaneously proposed with reference to the interactions between private entrepreneurs and public authorities of the local and central governments; therefore, they forced modifications in urban development plans afterward. However, they could be considered as successful projects since they succeeded in the solution of the problems of private property through innovative partnerships (Uslu and Yetim 2006).

Urban regeneration became one of the main topics of urban planning agenda in Turkey with the beginning of the 2000's. This period started with the 1999 
Marmara Earthquake (Genç 2008:118) because it reminded the fact that the general quality of the building stock is relatively low in Turkey and there is an urgent need to renew this stock as fast as possible. Depending on a broad consensus, urban regeneration appeared as a significant urban policy to increase that low quality.

Since then, there have been several planning acts about urban regeneration ${ }^{4}$. With reference to legislative frameworks determined by these acts, lots of urban regeneration projects have been proposed, especially in metropolitan cities. These projects are, mostly, developed under the protection of municipalities at the local level and the Housing Development Administration of Turkey at the national level. Sometimes these public institutions implement their own urban regeneration projects; sometimes they call for tenders for urban regeneration projects by private land development companies. Since the construction sector has been conceived as the locomotive sector of economic mobilization in this period, this administration became one of the actors, willing to increase the number of residential units produced by urban regeneration and squatter prevention projects. The number of residential units produced in this way is 143.021 until June 2018, which means approximately 17 percent of all houses produced by this administration ${ }^{5}$.

Subcontractors and land developers are quite successful in increasing the physical quality of building stock due to the recent advancements in construction technology. Municipalities and the Housing Development Administration have been eager to meet their expectations since they thought that urban regeneration could solve the problems they have been dealing with. Despite the stakeholders of the supporting party, the overall regeneration process cannot be defined as a winwin situation. With reference to many projects (see Photographs 1-4), it can easily be said that the costs of urban regeneration projects are more than the benefits, especially for low-income property owners and tenant who have been residing at the urban regeneration sites. The urban regeneration processes under the control of market actors have remained blind to the expectations of these users, which decrease the social legitimacy of urban regeneration projects (Levent 2010a, Levent 2010b) and increase the resistance against them.

In most cases, urban regeneration projects could not increase the overall urban qualities. The main reason why they could not contribute to urban quality is related to the fact that they are mostly proposed independently from the decisions of urban development plans aiming a coherent whole, as it can be observed from the examples. Although the regeneration areas are determined within the development plans, the density and land-use_decisions in those areas are not proposed in those plans. In such conditions, high-dense urban regeneration areas are like "black holes" vacuuming all technical infrastructure, social services, and green areas from the surrounding residential areas and producing a kind of predetermined

\footnotetext{
${ }^{4}$ The Act of Urban Regeneration Project for North Ankara City Gate No: 5104; The Act of Municipalities No: 5393; The Act of Conservation by Renovation and Use by Surviving of Deteriorated Cultural and Natural Entities No: 5366; and The Act of Urban Regeneration of Spaces under the Risk of Disaster No: 6306 are the basic acts organizing urban regeneration practices.

${ }^{5}$ The Summary Information about the Production of Residential Units by Housing Development Administration, http://www.toki.gov.tr/AppResources/UserFiles/files/FaaliyetOzeti/ozet.pdf (Last accessed: June 2018)
} 
insufficiency for those relevant settings. The dramatic results of these projects, additionally, become the loss of spatial coherence of urban land-uses, the weaknesses in urban unities and the breaks in public continuities through inconsistency and incongruity. Whether they are contiguous or not, most of the urban regeneration projects do not take existing urban socio-spatial context into account; and therefore, they are disconnected from the built environment (see Photographs 1-4).

Photograph 1. Inconsistent Urban Regeneration - I

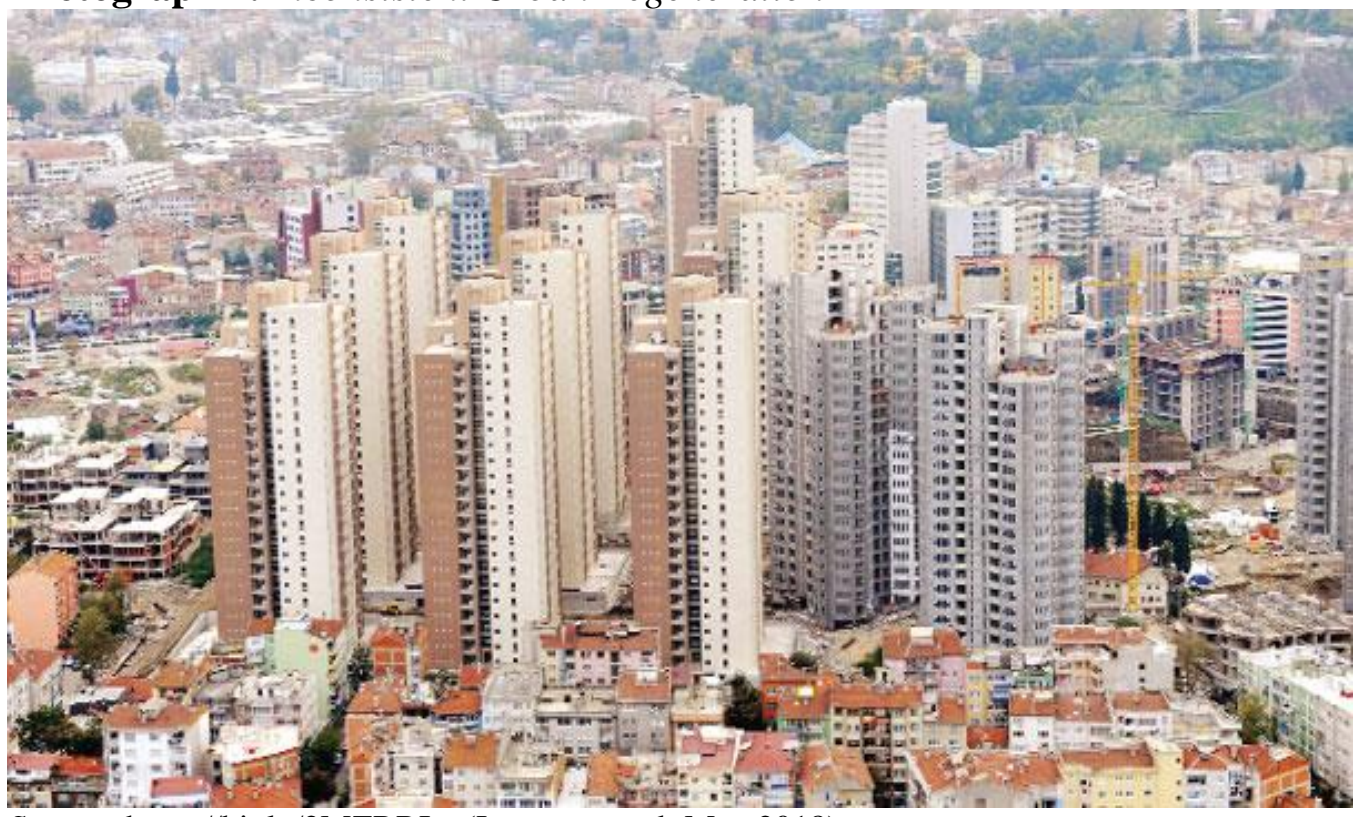

Source: https://bit.ly/2MZRRIw (Last accessed: May 2018)

Photograph 2. Inconsistent Urban Regeneration - II

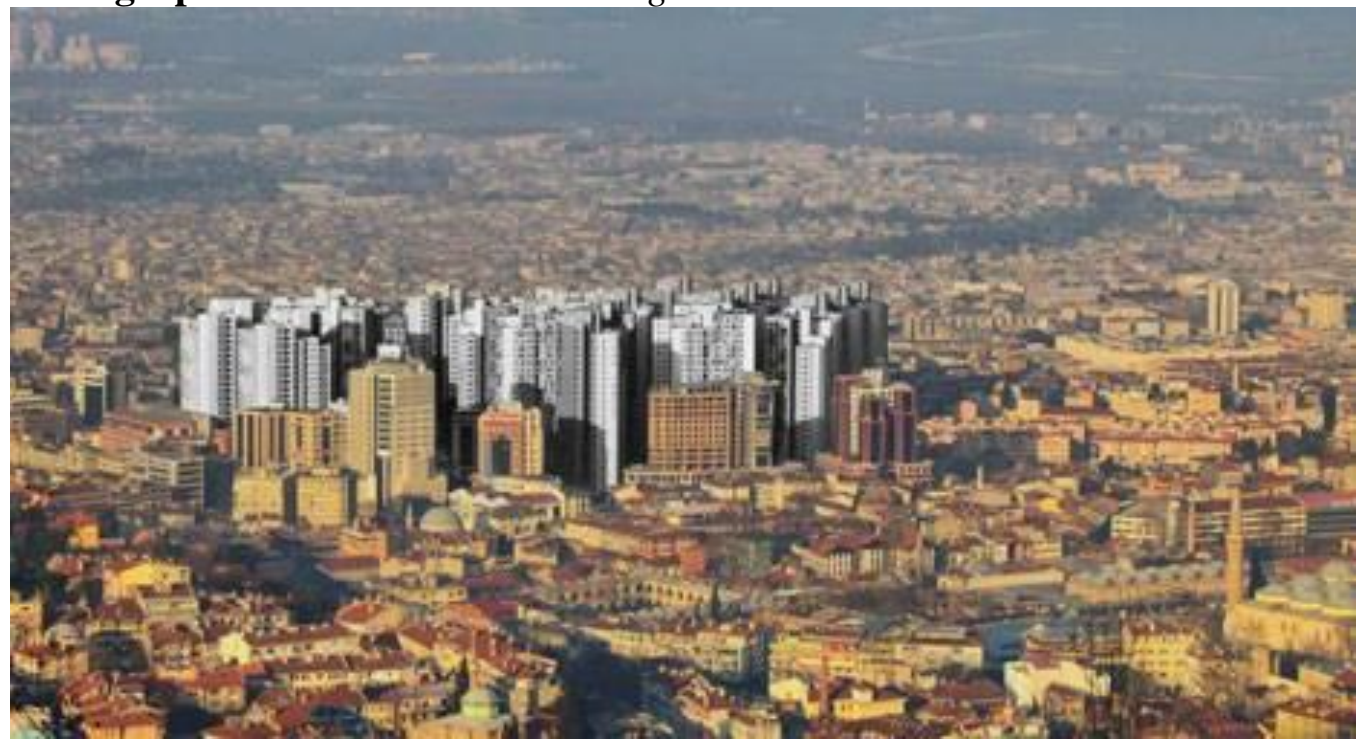

Source: https://bit.ly/2xyNCyA (Last accessed: May 2018) 


\section{Photograph 3. Incongruous Development through Urban Regeneration Projects I}

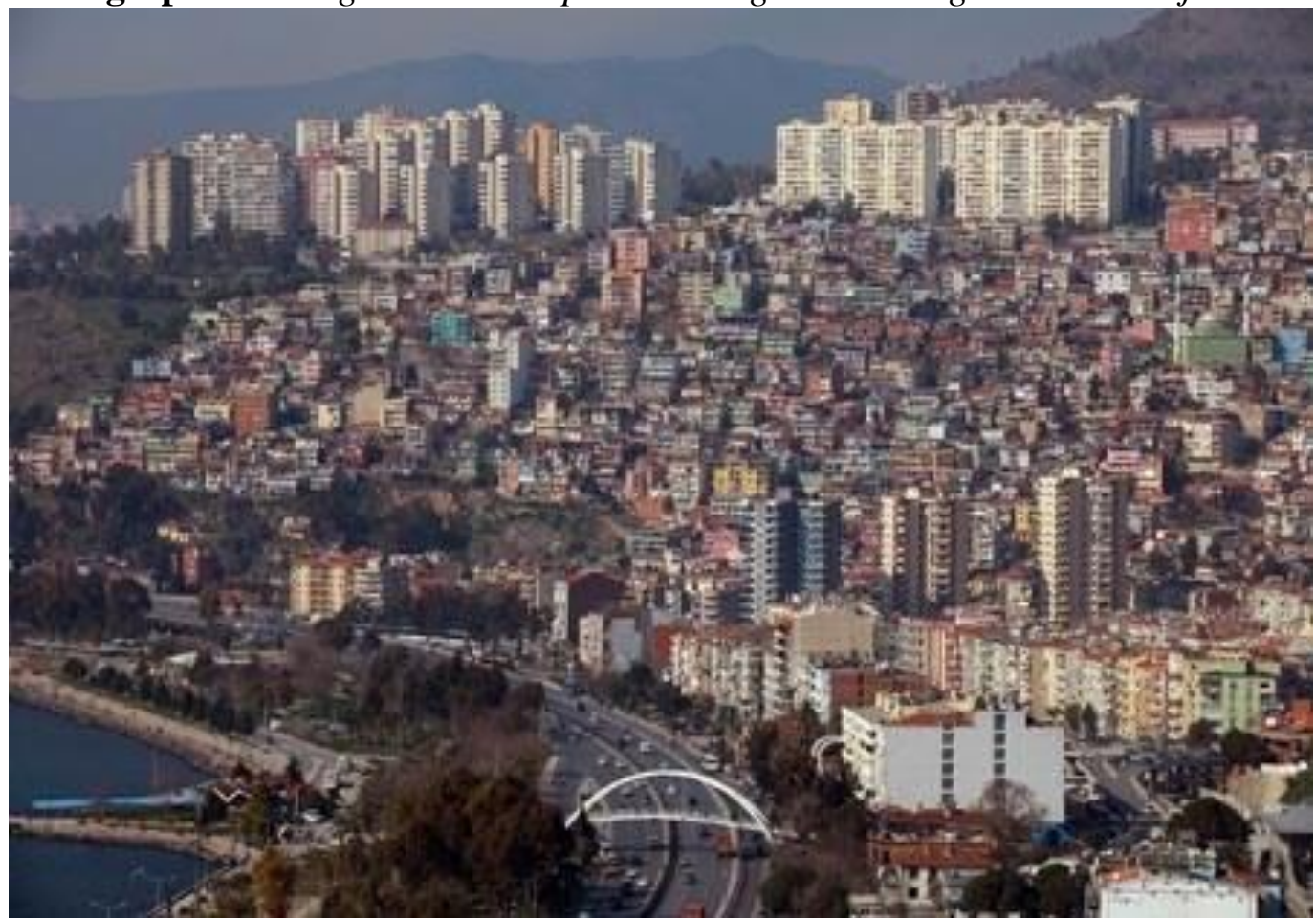

Source: https://bit.ly/2pvYMjk (Last accessed: May 2018)

Photograph 4. Incongruous Development through Urban Regeneration Projects II

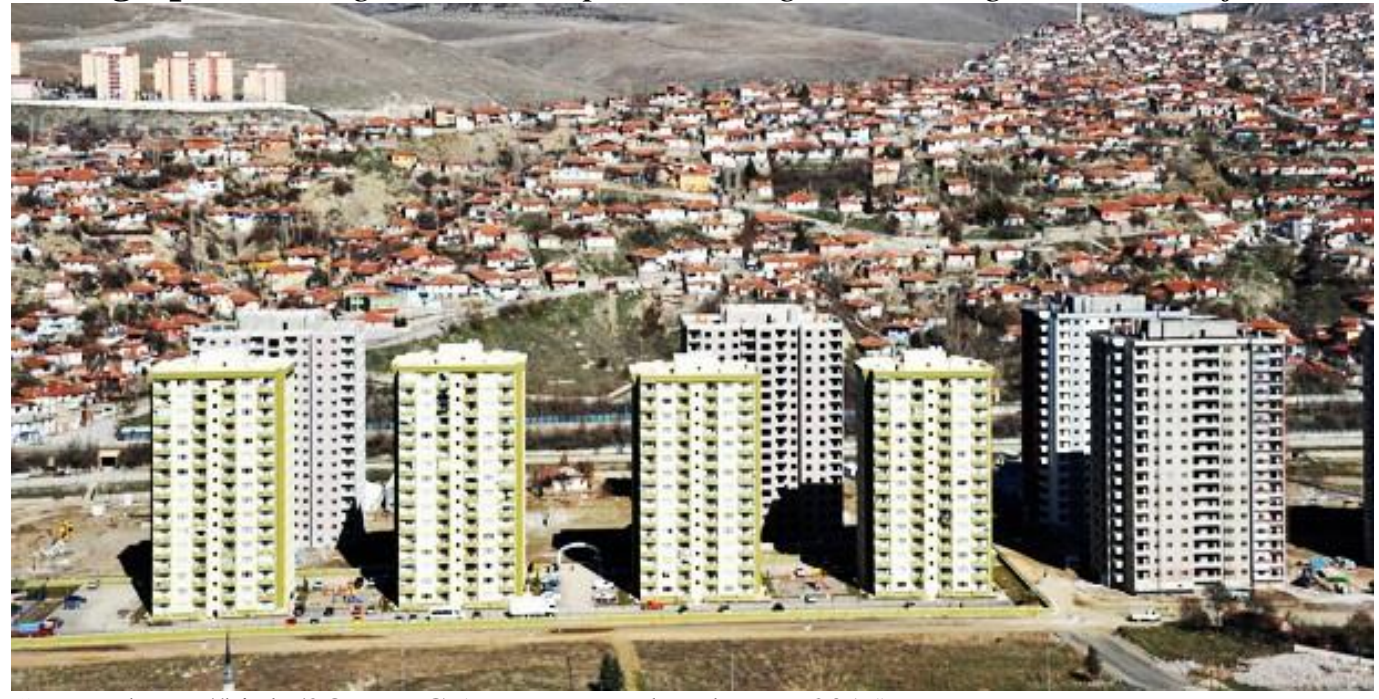

Source: https://bit.ly/2QXzyqG (Last accessed: February 2015)

\section{Problems of Urban Regeneration}

The problems of urban regeneration are not solely physical or spatial problems. There are other urban problems related to economic and social dimensions of cities which are as important as spatial problems. 
The basic problem in the economic dimension is the low levels of post-project gains of low-income property owners. Since urban regeneration projects change housing prices radically in most cases, property owners are forced to accept additional long-term debts in case of trade-offs between existing residential units and the ones produced through urban regeneration projects. Independent from the amount of these debts, most of the low-income property owners choose to sell their properties instead of accepting debt burdens due to economic uncertainties. Owning a residential unit in the regenerated areas does not solve all the problems related to economic dimensions. Another problem is the lack of financial abilities to afford to live in the regenerated residential areas. The cost of living in such areas becomes relatively high since there are new expense items such as building fees and heating expenditures different than before. Both of these facts are significant push factors displacing those low-income property owners (along with tenants, of course) from their residential settings to which they have been accustomed.

Pushing low-income property owners towards the distant locations in urban peripheries produces drastic effects on them. Their commuting relations are changed due to the increasing distance between residential units and workplaces. They now spend more money on transportation, which decreases their living standards. In order to reach their previous standards, these low-income people try to return back to residential areas where they can have similar commuting relations of their previous lives. In most cases, this is their basic strategy to reproduce similar daily routines of their past. However, there is a scarcity of potential residential units matching with their incomes and residential preferences. In these conditions, they try to solve this scarcity problem by collective action. Multiple households start to share single residential units, which means densification of residential areas, insufficiency of public services or, in short, problems of "quality of life" (see Image 1) ${ }^{6}$.

With reference to the social dimension, it can be easily said that urban regeneration creates significant changes in the social topographies of cities. These changes emerge with the ignorance of existing user groups in a non-participatory urban regeneration process. Since these processes have influences on displacing low-income property owners and tenants, they might cause social problems such as sociospatial segregation, social exclusion, and thus, social polarization.

${ }^{6}$ Çiftçioğlu, K., Sulukule: A Multi-Stakeholder Participatory Planning Process, https://bit.ly/2IjhH9L (Last accessed: June 2018) 
Image 1. The Changes in the Location of Families after Sulukule Urban Regeneration Project

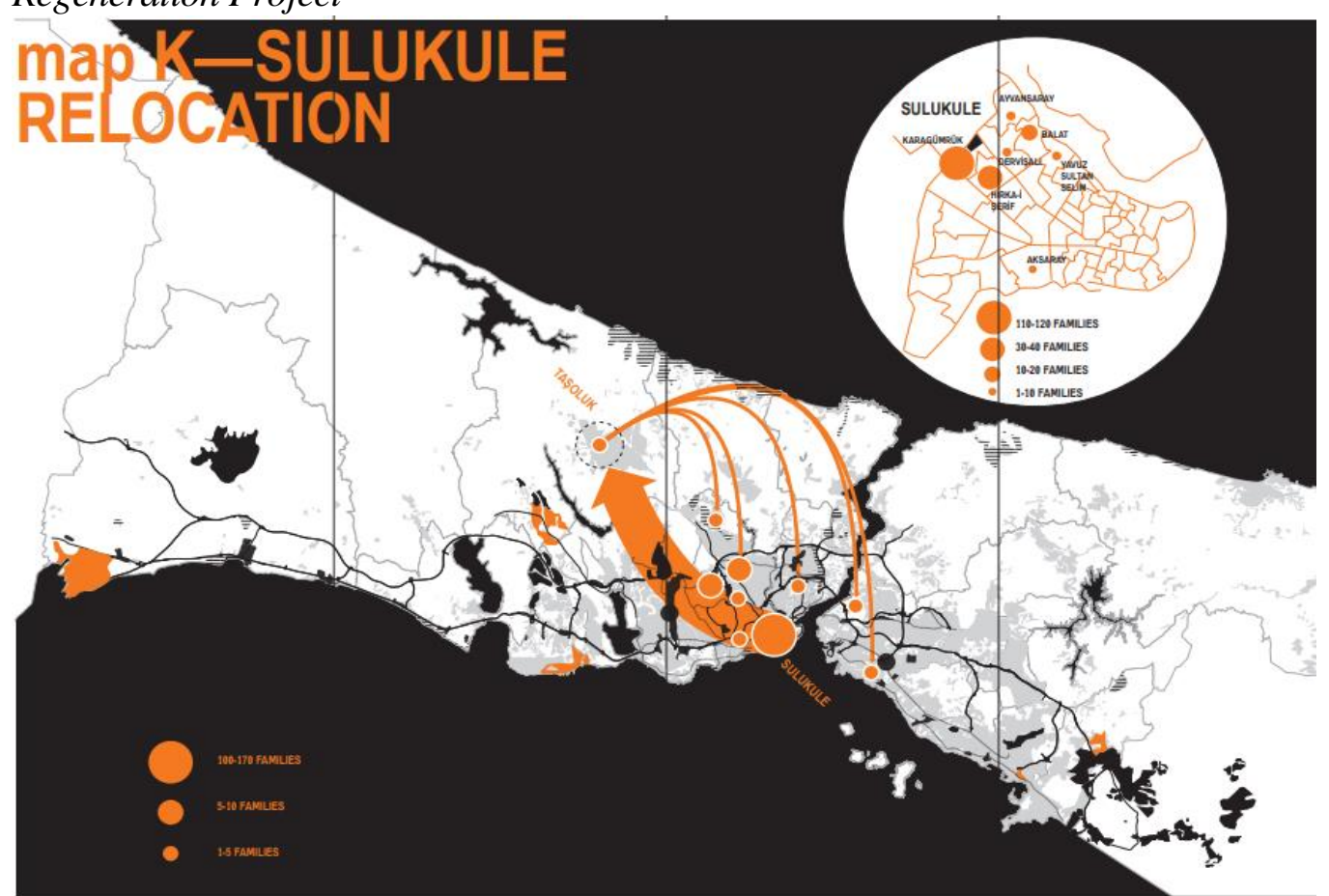

Source: https://bit.ly/2ND72wk (Last accessed: May 2018)

Although the initial motivation of urban regeneration is replacing unqualified buildings with the qualified ones as fast as possible, there is an obvious reluctance of land developers towards extremely unqualified residential areas. Despite the urgency in those areas, almost all urban regeneration projects are proposed for urban areas, where there might be some residential demands from the middle and high-income groups. This is quite understandable because these areas become profitable for land developers through these demands.

What is interesting with these regeneration areas is that they are either located either along the boundaries between residential areas for low-income groups and high-income groups or unqualified residential areas surrounded by high-income groups, which can be proven by the study in Ankara conducted by Ataç (2016). With these locational strategies, urban regeneration became a segregating process; increasing the heights of symbolic walls between different income groups and making them invisible to each other (see Image 2).

These problems do not mean that the urban regeneration projects have a decreasing tendency. Since they are still profitable for land developers; since they provide some opportunities for municipalities by solving problems of urban degradation and deterioration; and since central government and its public institutions think that these projects can give the economy a significant push, the number of urban regeneration projects increases year by year. According to lowincome land-owners and tenants, however, urban regeneration creates a kind of urban degeneration since it is a displacing, segregating, polarizing process that worsens their ways of urban living and existing urban regeneration practices are 
not acceptable without any change in their process.

Image 2. The Relation between Urban Regeneration and Socio-Spatial Segregation

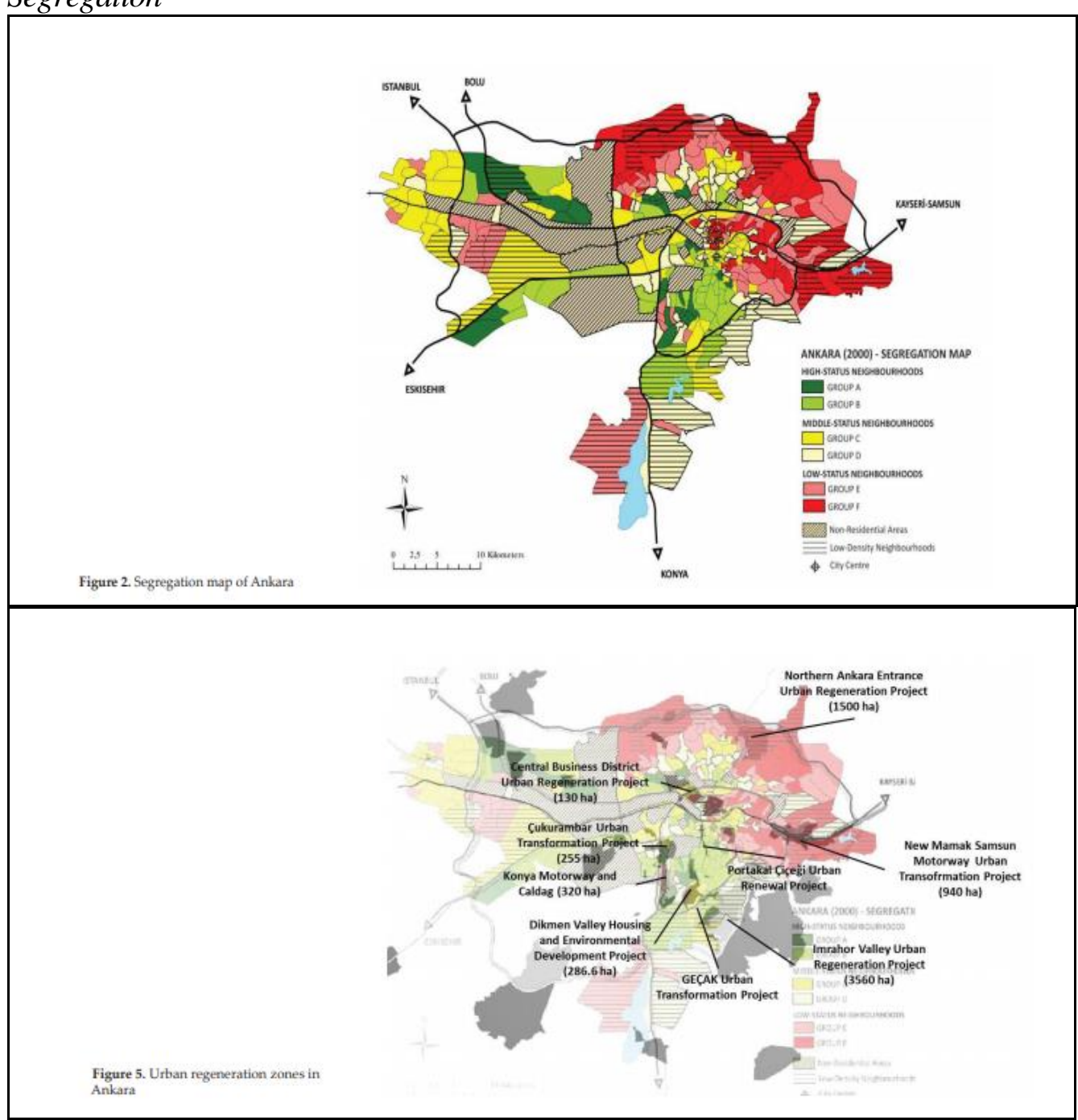

Source: https://bit.ly/2xQU7fq (Last accessed: May 2018).

\section{Conclusion}

Urban regeneration is an inevitable process in Turkey since it is one of the basic tools to direct urban development. Although it is supported by certain stakeholders, there are significant problems resulting from urban regeneration. There is an obvious need for modifications in the processes, priorities, and principles of existing urban regeneration. Without making these modifications, it might continue to produce negativities within the urban environment, at least, for low-income groups.

In the existing context, the only decisions about urban regeneration projects in spatial development plans are the boundaries of them. In terms of planning 
decisions, the projects do not depend on urban development plans. Instead, they are the immediate outcomes of simultaneous interactions among the actors of the market, central and local governments. They appear, mostly, as daily solutions for chronic urban problems (Genç 2008:123). Therefore, the endeavors aiming to organize urban regeneration activities fall, generally, behind the implementation (Türel et. al. 2005). The decisions about land-uses and densities in urban regeneration projects are independent of the decision frameworks of spatial plans and harm spatial coherence, unities, and continuities in urban structures. In that sense, the first thing that should be modified within the processes of urban regeneration is the relations between urban development plans and urban regeneration projects. All the decisions about urban regeneration should be given in development plans as detailed as possible so that the regenerated areas can be a part of the urban wholes.

Another modification should be achieved by reconsidering the priorities of urban regeneration. The main concept has to be comprehended in this reconsideration. Instead of focusing solely on the physical dimension of the urban environment (Akkar 2006:35), economic and social dimensions should be included in the urban regeneration process. As a concrete step, in the economic dimension, urban regeneration should increase post-project economic gains and create a kind of affordability-capacity to live in the regenerated residential areas for low-income groups. Increasing post-project economic gains might be achieved through eliminating certain restrictions on private properties, at least on the ones owned by low-income groups. Creating affordability might be achieved by either increasing household incomes or decreasing household expenditures. Finding jobs (with social security) for (at least) one member of all low-income households through official arrangements with the owners of those projects, for instance, might increase household incomes. On the other hand, municipalities might provide local public service subsidies for low-income groups in the regenerated areas in order to decrease household expenditures. With reference to the social dimension, urban regeneration projects should propose all-inclusive residential areas. In order to achieve inclusiveness, the starting point should be rethinking the participatory processes. All the stakeholders of the urban regeneration process should be equal in the participation platforms by declaring their needs and expectations, free in negotiations and fairly persuaded for public consensus (Levent and Sarkkaya Levent, 2011). In order to solve the problems of social dimensions, it is also possible to consider urban regeneration as parts of comprehensive social programs (Özden 2007:213).

These context-dependent propositions have to be, of course, combined with the general and universal principles of urban regeneration. According to Roberts (2000), through these principles, it is possible to achieve a comprehensive and multi-dimensional urban regeneration approach, which means the consideration of different dimensions that are actually neglected in the existing practice. The most important ideas of the principles of urban regeneration defined by Roberts (2000: 18-19) are: 
- performing a detailed analysis of the conditions of the urban regeneration area;

- considering simultaneous adaptation among built environment, social structures, economic base, and environmental conditions through comprehensive and integrated strategies;

- setting relations between strategies and the aims of sustainable development;

- having clear and operational objectives;

- searching for optimum use of all sources during the process;

- ensuring consensus through the fullest possible participation and cooperation of all stakeholders;

- having a monitoring mechanism on the progress of strategy towards the achievements of the specified objective and the changes and influences of internal and external forces acting upon urban areas;

- having easily-revisable and flexible programs of implementation.

By combining these ideas with the local context, it is possible to produce successful forms of urban regeneration and create capacities to eliminate existing negative aspects of urban regeneration. This is one of the ways to reach better futures for the Turkish cities.

\section{References}

Akkar ZM (2006) Kentsel Dönüşüm Üzerine Batı'daki Kavramlar, Tanımlar, Süreçler ve Türkiye [Western Concepts of Urban Regeneration, Definitions, Processes and Turkey]. Planlama Dergisi 2006(2): 29-38.

Ascher F (2001 March) La Nouvelle Revolution Urbaine: De La Planification au Management Stratégique Urbain [The New Urban Evolution: From Planning to Urban Strategic Management]. In Masboungi A (Ed) Fabriquer la Ville - Outils et Méthodes les Aménageurs Proposent. Paris: La Documentation Française.

Ataç E (2016) A Divided Capital: Residential Segregation in Ankara. METU JFA 33(1): 187-205.

Cheshire PC, Hay DG (1989) Urban Problems in Western Europe: An Economic Analysis. London: Unwin Hyman.

Couch C (1990) Urban Renewal: Theory and Practice. London: McMillan Education Ltd.

Couch C, Fraser C (2003) Introduction: The European Context and Theoretical Framework. In Couch C, Fraser C, Percy S (Eds) Urban Regeneration in Europe, 1-16. London: Blackwell Science Ltd.

Genç FN (2008) Türkiye'de Kentsel Dönüşüm: Mevzuat ve Uygulamaların Genel Görünümü [Urban Regeneration in Turkey: A General View of Regulations and Implementations]. Yönetim ve Ekonomi. 15(1): 115-30. Manisa: Celal Bayar Üniversitesi İ.̇̇.B.F.

Ginot B (2010) Urban Regeneration in Europe: State of the Art and Perspectives. An Analytical Study Interrogating Sustainability. Unpublished Master Thesis (2010-75). Sweden: Chalmers University of Technology.

Herdem K (2011) The Impacts of 1999 Marmara Earthquake on the Emergency Management Approach in Turkey. TODAIE's Review of Public Administration. 
$5(2): 187-214$.

Lang T (2005) Insights in the British Debate about Urban Decline and Urban Regeneration. Working Paper. Leibniz-Institute for Regional Development and Structural Planning (IRS). Erkner.

Levent T (2010a) Kent Planlamadan Kentsel Projeciliğe: Değişimin Kamusal Alanda Yarattı̆g Erozyonlar [From Urban Plans to Urban Projects: The Erosions in Public Realm resulted from this Change]. 8 Kasım Dünya Şehircilik Günü 32. Kolokyumu "Kentsel Yeniden Yapılanma: Kazananlar, Kaybedenler" Bildiriler Kitabı [In Proceedings of $32^{\text {nd }}$ Colloquium of November $8^{\text {th }}$ World Urbanism Day "Urban Restructuring: Winners and Losers"]. Ankara. 81-91.

Levent T (2010b) Esnek Planlama Yaklaşımları Üzerine Eleştirel Bir Değerlendirme: Bu Yaklaşımların Türkiye Bağlamında Yanılsamaları [A Critical Evaluation on Flexible Planning Approaches: The Illusions of these Approaches in the Turkish Context]. 8 Kasım Dünya Şehircilik Günü 33. Kolokyumu "Kentleri Korumak/Savunmak" Bildiriler Kitabl [In Proceedings of $33^{\text {th }}$ Colloquium of November $8^{\text {th }}$ World Urbanism Day "Protecting/Defending the Cities"]. Ankara, 633-653.

Levent T (2015a) Urban Regeneration in Turkish Context: An Evaluation through the Planning Acts. European Lawyer Journal 34(4): 45-60.

Levent T (2015b) Kentsel Dönüşüm üzerine bir Değerlendirme: Adana Örneği [An Evaluation on Urban Regeneration: The Case of the City of Adana]. Adana Kent Sorunlarl Sempozyumu 3" Bildiriler Kitabl [In Proceedings of the Symposium Of the Urban Problems in the City of Adana], 93-113.

Levent T, Sarıkaya Levent Y (2010) Bölgesel Gelişmede Ulus-Devletin Rolü: 1999-2009 Y1lları Arası Kamu Yatırımları Üzerinden Bir Değerlendirme [The role of the Nation-State in Regional Development: An Evaluation through Public Investment between Years 1999-2009]. Megaron. 5(3). 103-115.

Levent T, Sarıkaya Levent Y (2011) Küreselleşme, Mekansal Planlama Yaklaşımlarındaki Değişme ve Kamu Yararı [Globalization, Changes in Spatial Planning Approaches and Public Interest]. Toplum ve Demokrasi. 5(11-12): 53-74.

Özdemir D, Özden P, Sirma T (2005) Kentsel Dönüşümde Avrupa Deneyimi: Kuram ve Uygulamaya İlişkin Bir Değerlendirme [European Experience in Urban Regeneration: An Evaluation about Theory and Practice]. Ege Mimarlik. 2005/1(53): 22-9.

Özdemir Sönmez N (2006) Düzensiz Konut Alanlarında Kentsel Dönüşüm Modelleri üzerine bir Değerlendirme [An Evaluation about the Models of Urban Regeneration on Informal Residential Areas]. Planlama Dergisi 2006(2): 121-127.

Özden PP (2000) Kentsel Yenileme Uygulamalarında Yerel Yönetimleri Rolü Üzerine Düşünceler ve İstanbul Örneği [Ideas about the Roles of Local Authorities in Urban Renewal Implementations and the Istanbul Case]. İstanbul Üniversitesi Siyasal Bilgiler Fakültesi Dergisi "Prof. Dr. Nazif Kuyucuklu'ya Armağan". 23-24: 255-69.

Özden PP (2007) Belediyelerin Sosyal Programları ve Kentsel Yenileme [The Social Programs of Municipalities and Urban Renewal]. In Yerel Yönetimler Üzerine Güncel Yazılar, M. Kösecik and H. Özgür Eds. Nobel Yayın. Ankara, 197-225.

Pryor T (1968) Defining the Rural-Urban Fringe. Social Forces 47(2): 202-215.

Roberts P (2000) The Evolution, Definition, and Purpose of Urban Regeneration. In Roberts P, Sykes H (Eds) Urban Regeneration: A Handbook, 9-36. London: Sage Publications.

Sağlam S (2006) Türkiye'de İç Göç Olgusu ve Kentleşme [The Migration Phenomenon in Turkey and Urbanization]. Türkiyat Araştırmaları 5: 33-44.

Tsenkova S (2002) Introduction. In Tsenkova S (Ed) Urban Regeneration: Learning from the British Experience, 1-8. Calgary: The University of Calgary.

Türel A, Osmay S, Güvenç M, Ataöv A, Akkar M (2005) İstanbul Eylem Planlamasına 
Yönelik Mekansal Gelişme Stratejiler: Araştırma ve Model Geliştirme Çalışmaları [Spatial Development Strategies for Istanbul Action Planing: Analysis and Model Development Studies]. Ankara: ODTÜ Şehir ve Bölge Planlama Bölümü.

Uslu A, Yetim L (2006) Çağdaş Kentsel Çevre Yaratma Çabalarına Bir Örnek: Ankara / Portakal Çiçeği Vadisi Kentsel Dönüşüm Projesi [An Example for the Efforts of Creating Contemporary Urban Environment: Ankara / Urban Regeneration Project in Protakal Çiçeği Vadisi]. Tekirdăg Ziraat Fakültesi Dergisi. 3(2): 169-179.

Uzun CN (2006) Yeni Yasal Düzenlemeler ve Kentsel Dönüşüme Etkileri [New Regulations and their Influences on Urban Regeneration]. Planlama Dergisi. 2006(2): 49-63.

Yiğitcanlar T (2001) Kentsel Yenileme Olgusu ve Gelişim Süreci [The Phenomenon of Urban Renewal and its Development Process]. Planlama Dergisi. 2001(4): 55-58. 